\title{
DEVELOPMENT OF THE EDUCATIONAL EXPERTS' PROFESSIONAL COMPETENCE IN CONDUCTING INSTITUTIONAL AUDIT IN EDUCATIONAL INSTITUTIONS
}

\author{
Lyudmila Aleksieienko-Lemovska \\ Candidate of Pedagogic Sciences, Associate Professor, \\ Head of the Department of Institutional Audit, State Service for Education Quality \\ in Kyiv Region, Ukraine \\ e-mail: al-lem17@ukr.net,orcid.org/0000-0001-5391-0719
}

\section{Summary}

The article considers the professional competence of educational experts in conducting the institutional audit of educational institutions is an integral multi-level professionally significant characteristic of the personality and activities of a specialist, based on effective professional experience; reflecting the systemic level of functioning of methodological, methodological and research knowledge, skills, experience, motivation, abilities and readiness for creative self-realization in expert activity, presupposes an optimal combination of methods of professional scientific-pedagogical and pedagogical activity. The development of professional competence is the development of a creative individuality, susceptibility to the pedagogical innovations, the ability to adapt to changes in the pedagogical environment.

A structural and functional model has been developed that enables identification of interrelated components: goals, objectives, pedagogical conditions, principles, functions, stages, forms and methods of work, criteria, indicators and levels of development of educational experts professional competence in conducting institutional audit in educational institutions. The following theoretical research methods were used to solve certain problems: systematic analysis, comparison, systematization, classification and generalization of scientific and methodological literature on the problem of development of competence; method of systematic analysis of philosophical, psychological-pedagogical, sociological literature for theoretical generalization of leading scientific approaches to the development of educators' competence; interpretation of key provisions of the study.

Keywords: competence approach, professional competence, educational process, pedagogical model, levels, criteria, indicators.

DOI https://doi.org/10.23856/3919

\section{Introduction}

Changes taking place in the modern education system are determined by the need for increased teachers' professional development and professionalism, their professional competence. The competence-based education model arises from education modernization aimed at preparing the individual for life, identity formation, as well as general preparation for the fulfillment of the whole range of social functions. As a result, there is a shift in the assessment of educational outcomes from the concepts of "education", "good breeding", "preparedness" to the ideas of "competence" and "competency". Professional and pedagogical competence covers the field of knowledge and methods of forming a set of skills and determines the dependence of the development of this competence on the quality of professional activity.

The urgency of this problem is caused by: the changes in the legal aspect of national education, updating the legal and regulatory framework of Ukraine; objective requirements for 
the development of a system for ensuring the quality of education in educational institutions; society's requirements for educational experts capable of self-development and self-education in the innovative professional environment; the need to ensure a high level of pedagogical interaction between educational experts and participants in the educational process; the need for a systematic approach to the problem of developing professional competence in the field of education; the need for practice in methodological support of the process of implementing a competence-based approach in the professional training of educational experts; activation of the role of professional competence, relevant in the context of modernization of modern pedagogical education.

The purpose of this study is to develop approaches for determining the specifics and content of the professional competence of educational experts in conducting institutional audit in educational institutions, the scientific and research task is to substantiate the concept of developing the educational experts' professional competence in conducting institutional audit in educational institutions.

The methodological basis of the research is developed based on taking into account the provisions of functional-activity, axiological, universal, personality-activity approaches.

\section{The essence and specific aspects of the educational experts' professional competence}

The realization of systemic educational reforms is envisaged by the changes that have occurred in the legal aspect of national education, updating the regulatory and legislative framework of Ukraine: the Laws of Ukraine "On Education", "On Secondary Education" and others. The dominant feature of these changes is human-oriented education, that is, education for a person, and its core is the developmental, cultural-creative content of teaching and educating a responsible, competent person. It is noted that education is a State priority, which ensures the innovative, socio and economic and cultural development of society.

According to Ukrainian legislation, the institutional audit, the purpose of which is to assess the quality of education and the quality of educational activities of an educational institution, involves experts - teachers who have passed certification and / or have the highest qualification category, Heads (deputy heads) of educational institutions that have passed the institutional audit, as well as other specialists with higher professional education and / or professional qualifications of a teacher, practical work experience in an educational institution for at least 5 years and have undergone appropriate training.

Thus, the need to develop the educational experts' professional competence in conducting institutional audit in educational institutions is due to new trends in the information society associated with the accumulation of scientific knowledge and the need to find effective mechanisms for its transfer and use.

Under conditions of modernization of education, the transition from theory to practice requires competent thinking from a modern specialist. A competent specialist is characterized by knowledge in his subject area, personal and humanistic orientation, possession of modern pedagogical technologies, the ability to integrate with experience, creativity in the professional sphere, the presence of a reflective culture.

Competence to covers not only cognitive and operational-technological components, but also motivational, ethical, social, and behavioral ones including learning outcomes, a system of value orientations. Thus, competences are formed not only during training but also under the influence of family, friends, work, politics, religion, etc. (Hluzman, 2009).

A necessary component of an individual's professionalism is professional competence. Modern professional competence approaches and its interpretations are quite different. 
The definitions of professional competence as «in-depth knowledge», «the state of adequate task performance», «the ability to fulfill a task in a timely manner» are prevailing. In order to gain professionalism, it is required to have appropriate abilities, desires and personality traits, a willingness to constantly learn and improve one's skills (Sharmahd, 2018).

Since the teaching profession is simultaneously transforming and managing, the concept of a teacher's professional competence expresses the unity of his theoretical and practical readiness to carry out teaching activities and characterizes his professionalism. In this regard, professional competence is determined by the level of manifestation of professional readiness for the implementation of professional activity (Edwards, 2006).

The professional competence of an educational expert is the ability to solve professional problems, tasks in the context of professional activity; the stock of knowledge and skills, which determines the effectiveness and efficiency of labor, a combination of personal and professional qualities. It is determined by a motivated desire for continuous education and self-improvement, a creative and responsible attitude to work. The competence of a specialist - teacher is manifested in his knowledge, awareness, authority in the pedagogical field.

According to the definition of the "professional competence" concept, it is proposed to assess the level of the educational experts professional competence in conducting institutional audit in educational institutions using three criteria: possession of modern pedagogical technologies and their application in professional activities; readiness to solve professional subject problems; the ability to control their activities in accordance with the accepted rules and regulations.

So, the professional competence of educational experts in conducting the institutional audit of educational institutions is an integral multi-level professionally significant characteristic of the personality and activities of a specialist, based on effective professional experience; reflecting the systemic level of functioning of methodological, methodological and research knowledge, skills, experience, motivation, abilities and readiness for creative self-realization in expert activity, presupposes an optimal combination of methods of professional scientific-pedagogical and pedagogical activity.

The development of professional competence is the development of a creative individuality, susceptibility to the pedagogical innovations, the ability to adapt to changes in the pedagogical environment.

New requirements for the teacher education quality imply the need for changes in the organization, content, technology and scale of educational experts training for the institutional audit of educational institutions.

\section{The concept of development of educational experts' professional competence}

A structural and functional model has been developed that enables identification of interrelated components: goals, objectives, pedagogical conditions, principles, functions, stages, forms and methods of work, criteria, indicators and levels of development of educational experts professional competence in conducting institutional audit in educational institutions.

The key idea of the concept is to apply a systemic, competence-based and environmental approaches to the development and implementation of the model and methodology for the development of professional competence, taking into account previous preparedness and predicting the possibilities of further professional individual growth (Aleksieienko-Lemovska, 2020).

The concept is based on a methodological, theoretical and methodological level.

The methodological guidelines are the principles of taking into account individual and collective forms of expert activity, anticipatory response, productivity, coverage, problematicity and professional expediency. 
So, the choice of the personality self-development principle is due to the need for constant independent work related to the study of the essence and content of professional competence. In order to activate the expert activity of educational experts, it is necessary to form cognitive motives; involve in various types of independent work on the study of teaching materials; equip educational experts with innovative methods and forms of organizing expert activities in educational institutions.

The principle of combining individual and collective forms of work. According to the number of participants, the following forms of work can be distinguished: personal (single person or with the participation of two partners who are in different institutions, organizations, regions, countries); paired (between pairs of participants); group (between groups of participants). The modern interpretation deepens this principle associated with personal and individual orientation, relying on the individuality of each person, up to the definition of individual learning paths with the right to choose the level and methods of mastering the programs, with the wider use of computer programs, but with the inclusion of each in collective forms of work.

The principle of productivity is due to the essence of expert activity and its focus on the mandatory result receipt - product creation. The principle of productivity emphasizes the pragmatism of the activity, the obligatory orientation towards obtaining a result that has applied significance. In other words, towards the "product design" of the design process results.

The step-by-step principle is determined by the essence of expert activity, since each issue of organizing expert activity involves the passage of certain stages. The principle of stepby-step specifies the idea, which is expressed in the definition of stages and resources, means and methods of achieving the result, in the creation of a specific program of action. And each subsequent action is based on the results of the previous one.

The basis of the principle of the problematic nature of the content and process of education is made up of three important interrelated components: the problem - the educational content unit; problem task - the educational process unit; problem situation - the unit of relations between a problem and problem tasks as units of content and educational process.

The principle of professional expediency is one of the basic principles in the development of the educational experts' professional competence. The implementation of this principle presupposes a wide variety of content and forms of the educational process. Pedagogical practice is the effective criterion for the truth of scientific knowledge, the provisions that are developed by theory and partially verified by experiment. Practice is also becoming a source of new fundamental problems in education. Theory, therefore, provides a basis for correct practical solutions, but global problems, tasks that arise in educational practice, give rise to new questions that require fundamental research.

The methodological level ensures the implementation of a complex of psychological and pedagogical conditions: the presence of a value attitude towards expert activity based on the integration of a personal position and general cultural, psychological, pedagogical, methodological and methodic knowledge, updating the individual experience of the educational expert; inclusion of the expert in active creative interaction in educational systems on the basis of "subject- subjective" relations; implementation of differentiated holistic support of the activity of the educational expert, which has an analytical nature and involves the development of professional skills and abilities necessary for the independent implementation of expert activities (self-organization, self-regulation) integration of the educational environment of the educational institution, the State Service of Education Quality of Ukraine and its territorial bodies, higher educational institutions, institutions of postgraduate pedagogical education and other stakeholders; methodological support for the organization of expert activities and systemic monitoring of the state of development 
of the educational experts professional competence; motivation for constant professional and methodological self-development and self-improvement, reflection of pedagogical actions at various stages of activity (introspection, self-assessment).

The theoretical level determines the theoretical aspects of the problem of the educational experts professional competence development, determines the structure of the educational experts professional competence, including the following components: personal, cognitive, activity.

We correlate the personal component of the educational experts professional competence with the skills associated with the psychological aspect of personality development: communicative, perceptual, reflexive.

The cognitive component is based on the skills that ensure the theoretical training of educational experts: analytical and synthetic (the ability to analyze programmatic and methodological documents, identify methodological problems and determine the ways to solve them, the ability to classify, systematize methodological knowledge); prognostic (the ability to predict the effectiveness of the selected means, forms, methods and techniques, the ability to apply professional knowledge, abilities, skills in new conditions); constructive and design (the ability to structure and build the educational process, select the content and forms of classes, select methods, methods and techniques, the ability to plan expert activities).

The activity component includes the accumulated professional knowledge and skills, the ability to update them at the right time and use them in the process of realizing their own professional functions. It also assumes the mastery of research and creative skills by the educational expert.

The methodological level provides for the creation of methodological support for the professional activities of educational experts, criteria (motivational, cognitive, methodological and operational), indicators and levels of development of professional competence, monitoring of its effectiveness; is based on modern scientific approaches, general pedagogical and methodological principles, takes into account the specifics of training and retraining of educational experts for the specified type of activity.

The tasks for the developing of the educational experts professional competence must be resolved in the process of professional training and retraining, enriching the level of the educational experts professional competence, improving the methodological tools for organizing training and creating educational and methodological support that would maximally take into account the peculiarities of the educational environment.

The development of the educational experts professional competence is a process that continues throughout the entire professional and pedagogical activity, therefore, it is not possible to determine the time frame of the professional competence formation stages (as, for example, in a higher education institution). At the same time, we distinguish three levels of development of the educational experts professional competence: basic (the development occurs at the existing level of professional competence in the individual mode of methodological support); productive (the educational expert is an active participant in the education quality assurance system); creative (the development process takes place independently on the basis of self-realization, is of a research and creative nature); at the same time, the process of developing professional competence is viewed as a multi-level one.

The main concept provisions determine that the development of the educational experts professional competence will be effective if a multi-level organization of study is provided: at the strategic level - training of educational experts, study of practical experience presented in the media and periodicals; at the tactical level - changes in approaches to the organization of expert activities, methodological training of educational experts; at the operational level - direct 
organization of training of educational experts, updating methods and techniques of professional training; updating the content of training modules; the use of diagnostic systems for the purpose of monitoring the quality of the organization of expert activities in modern educational institutions.

One of the key concepts of the structural-functional model is the function. We single out the following functions the educational experts' professional competence: gnostic, prognostic, organizational, communicative and reflexive.

The criteria of a professional orientation are the emotional and cognitive attitude to professional activity; activity of experts in preparation for professional activity; cognitive and active attitude to the formation of professional independence. Levels of development of the educational experts' professional competence: admissible, productive, creative.

\section{Conclusions}

The analysis of the current stage of the professional pedagogical education development allows us to assert that the improvement of the training system and retraining of educational experts in conducting institutional audits in educational institutions should be considered not only from the point of view of mastering the theory and teaching methods, mastering pedagogical concepts, but also from the point of view of high level of their readiness and ability to solve non-traditional pedagogical problems in various situations of the educational process, determining the need for systematic purposeful work to develop the professional competence of educational experts, that is, to introduce a pedagogical model of its formation.

\section{References}

Verkhovna Rada of Ukraine (2019) Zakon Ukrainy «Pro osvitu» № 2657-VIII. 2661 [Law of Ukraine “On Education”]. Vidomosti Verkhovnoi Rady Ukrainy. Retrieved from: https://zakon. rada.gov.ua/laws/show/2145-19.

Verkhovna Rada of Ukraine (2020) Zakon Ukrainy «Pro povnu zagal'nu serednyu osvitu» № 463-IX [Law of Ukraine on Complete General Secondary Education № 463-IX]. Retrieved from: https://zakon.rada.gov.ua/laws/show/463-20.

Verkhovna Rada of Ukraine (2019) Poryadok provedennya insty'tucijnogo audy'tu zakladiv zagal'noyi seredn'oyi osvity [Procedure for conducting institutional audit of general education instituions]. Retrieved from: https://zakon.rada.gov.ua/laws/show/z0250-19.

Hluzman, O. V. (2009). Bazovi kompetentnosti: sutnist ta znachennia v zhyttievomu uspikhu osobystosti [Core competence: the nature and value of individual success in life]. Pedahohika i psykholohiia, no. 2, pp. $51-60$.

Aleksieienko-Lemovska, L. V. (2020). Diagnostics of Methodological Competence Development of Preschool Teachers. Scientific and Technical Revolution Yesterday Today and Tomorrow, p. 731-739.

Edwards R., Nicoll K. (2006). Expertise, competence and reflection in the rhetoric of professional development. British Educational Research Journal, no. 32, pp. 115-131.

Sharmahd N., Peeters J., Bushati M. (2018). Towards continuous professional development: Experiencing group reflection to analyse practice. European Journal of Education, no. 53 (1), pp. $58-65$. 